\begin{tabular}{|l|l|l|l}
\hline Phytocoenologia & $36(2)$ & $161-189$ & Berlin-Stuttgart, June 14, 2006
\end{tabular}

\title{
A differentiating method for seed bank analysis: validation and application to successional stages of Koelerio-Corynephoretea inland sand vegetation
}

\author{
by Carsten EichberG*, Christian Storm*, Anselm Kratochwil ${ }^{* *}$ and \\ Angelika SchWABE*, Darmstadt* and Osnabrück** \\ with 4 figures and 5 tables
}

\begin{abstract}
Sampling of soil seed banks is known to be methodologically difficult, as diaspore distribution in soil is often patchy. Especially rare plant species are inherently difficult to detect. In our study we validated the accuracy of a sampling method which is based on a high number of individual sample units (100 soil cores/plot, altogether 12 plots) gathered by means of a random-systematic sampling design. We used this method in the course of a case study on successional stages of endangered inland sand vegetation in two areas of Germany. We analysed seed bank composition, proportion of endangered species, similarity between seed bank and aboveground vegetation and grazing impact.
\end{abstract}

(1) Methodological approach. The method produced results with high representativeness. On average, about $78 \%$ (topsoil: $1-6 \mathrm{~cm}$ depth) and $72 \%$ (subsoil: $11-16 \mathrm{~cm}$ ) of the species (jackknife estimator) were detected. The mean SøRENSEN distance between 9 and 10 composite samples (each consisting of 10 soil cores) was low $(<0.05$ topsoil, $<0.1$ subsoil). Ordination of the topsoil samples revealed a high degree of homogeneity of the composite samples.

(2) Case study. The soil seed banks of mid-successional stages (Diantho-Armerietum, Armerio-Festucetum) were significantly richer in species and diaspores than the associated pioneer stages (Spergulo-Corynephoretum, Koelerion glaucae). The seed banks of the base-rich successional series were significantly richer in plant species (parallel to aboveground vegetation) as well as in diaspores than the seed banks of the acidic series. Diaspores of many pioneer species were found in very low densities (e.g. Corynephorus canescens) in the soils of mid-successional stages or were not found in these stages (e.g. Phleum arenarium). Therophytes with higher ability to colonise gaps in mid-successional stages accumulated seed banks, albeit mostly in low densities. Among them were two Red List species (Medicago minima, Vicia latbyroides). With some exceptions (e.g. Vicia lathyroides) diaspores of Red List species were found in low abundances in the seed banks ( $<50$ diaspores $\mathrm{m}^{-2}$ in topsoil as well as in subsoil). Among the Red List species detected in the aboveground vegetation one of four species $(25 \%$, acidic series) or seven of 12 species ( $58 \%$, basic series) were detected in the seed banks. A twoyear period of extensive sheep grazing did not alter seed banks of Koelerion glaucae and Armerio-Festucetum stands.

Keywords: grazing impact, jackknife estimator, rare species, seed bank versus aboveground vegetation, SøRENSEN distance, species-area curves. 